\title{
ANALISA PERBANDINGAN FUZZY LOGIC METODE TSUKAMOTO, SUGENO, MAMDANI DALAM PENENTUAN KELUARGA MISKIN
}

\author{
Beben Sutara ${ }^{1}$, Heri Kuswanto ${ }^{2}$ \\ ${ }^{1,2}$ Program Studi Teknik Informatika, STMIK Sumedang, Indonesia \\ bensu@stmik-sumedang.ac.id ${ }^{1}$, zaizen182@gmail.com²
}

\begin{tabular}{ll}
\hline & Abstrak \\
\cline { 2 - 3 } $\begin{array}{l}\text { Kata Kunci: } \\
\text { Kemiskinan; }\end{array}$ & $\begin{array}{l}\text { Penerapan metode Fuzzy Tsukamoto, Sugeno, dan Mamdani dalam menentukan } \\
\text { keluarga miskin di Kabupaten Sumedang dapat dilakukan oleh ketiga metode dengan } \\
\text { hasil keluarga yang tergolong miskin yang berbeda-beda dilihat dari hasil perhitungan } \\
\text { Tsukamoto } ;\end{array}$ \\
Semua data. Dari semua data yang dihitung menggunakan metode fuzzy logic dengan \\
Tsukamoto, Sugeno, dan Mamdani disimpulkan bahwa pada metode Tsukamoto \\
Mamdani.
\end{tabular}

\begin{tabular}{|c|c|}
\hline & Abstract \\
\hline $\begin{array}{l}\text { Keywords: } \\
\text { Poverty; } \\
\text { Fuzzy Logic; } \\
\text { Tsukamoto; } \\
\text { Sugeno; } \\
\text { Mamdani. }\end{array}$ & $\begin{array}{l}\text { The application of the Fuzzy Tsukamoto, Sugeno, and Mamdani methods in } \\
\text { determining poor families in Sumedang Regency can be done by the three methods } \\
\text { using poor family outcomes which differ from the results of all data calculations. } \\
\text { From all data calculated using the fuzzy logic method of the Tsukamoto, Sugeno, and } \\
\text { Mamdani methods, it can be concluded that there are } 4 \text { data classified as poor and } 16 \\
\text { data classified as not poor in the Tsukamoto method, } 8 \text { data classified as poor and } 12 \\
\text { data classified not poor in the Sugeno method, and } 10 \text { data classified as poor and } 10 \\
\text { classified as not poor in the Mamdani method. These results indicate that each method } \\
\text { has different results even though the input used is the same. }\end{array}$ \\
\hline
\end{tabular}

\footnotetext{
${ }^{\otimes}$ Alamat korespondensi:

E-mail: bensu@stmik-sumedang.ac.id

p-ISSN: 2087-1627, e-ISSN: 2685-9858
} 


\section{Pendahuluan}

Pada umumnya di negara berkembang seperti Indonesia permasalahan pendapatan yang rendah dengan masalah kemiskinan merupakan permasalahan utama dalam pembangunan ekonomi [1]. Masalah kemiskinan semakin terlihat jelas dengan melihat data dari Badan Pusat Statistik (BPS). merilis, kemiskinan di Indonesia meningkat sebanyak 6.900 orang selama September 2016 hingga Maret 2017. Kemiskinan adalah suatu keadaan yang menyangkut ketidakmampuan dalam memenuhi tuntutan kehidupan yang paling minimum, khususnya dari aspek konsumsi dan pendapatan. sehingga untuk menanganinya dibutuhkan pendekatan yang terpadu, komprehensif dan berkelanjutan [2].

Pada penelitian ini, dalam menentukan keluarga miskin berdasarkan kriteria yang ditentukan oleh pemerintah memungkinkan munculnya ketidakpastian. Maka, masalah yang diangkat pada penelitian ini adalah bagaimana menentukan keluarga miskin berdasarkan kriteria yang sudah ditentukan oleh pemerintah dengan menggunakan metode Fuzzy logic.

Logika Fuzzy adalah metodologi sistem kontrol pemecahan masalah, yang cocok untuk diimplementasikan pada sistem, mulai dari sistem yang sederhana, sistem kecil, embedded system, jaringan PC, multi-channel atau workstation berbasis akuisisi data, dan sistem control [3].

Fuzzy logic yaitu logika yang digunakan untuk menggambarkan ketidakjelasan. Fuzzy logic ini memiliki tiga metode yaitu metode Fuzzy Tsukamoto, Sugeno, dan Mamdani dan dari ketiga metode Fuzzy ini memiliki mesin inferensi dan defuzzifikasi yang berbeda [4]. Sehingga, dengan menerapkan metode Fuzzy logic ini tepat untuk menentukan keluarga miskin pada penelitian ini. Namun ketiga metode tersebut belum diketahui metode Fuzzy mana yang tepat untuk diterapkan.

Kelebihan logika Fuzzy adalah kemampuannya dalam proses penalaran secara bahasa sehingga dalam perancangannya tidak memerlukan persamaan matematik yang rumit. Beberapa alasan yang dapat diutarakan mengapa menggunakan logika Fuzzy diantaranya adalah mudah dimengerti, memiliki toleransi terhadap data-data yang tidak tepat, mampu memodelkan fungsi-fungsi nonlinear yang sangat kompleks, dapat membagun dan mengaplikasikan pengalaman-pengalaman para pakar secara langsung tanpa harus melalui proses latihan, dapat bekerja sama dengan teknik-teknik kendali secara konvensional, dan didasarkan pada bahasa alami.

Beberapa penelitian telah banyak dilakukan terkait dengan penentuan keluarga masyarakat tidak mampu dengan menggunakan fuzzy logic, dilakukan oleh [5]-[7] yang menngunakan fuzzy sebagai pendukung keputusan dalam penilaian keluarkan miskin.
Dalam penelitian ini melakukan komparasi dimana dalam ini dilakukan perbandingan kondisi yang ada di dua tempat, apakah kedua kondisi tersebut sama, atau ada perbedaan, dan kalau ada perbedaan, kondisi di tempat mana yang lebih baik [8], dalam hal ini penerapan logika Fuzzy dilakukan.

Dengan menerapkan dan membandingkan Fuzzy logic metode Tsukamoto, Sugeno, dan Mamdani untuk menentukan keluarga miskin dilakukan pada salah satu Desa di Kabupaten Sumedang berupa penyusunan perhitungan sistematis, sehingga mendapatkan output nilai sebagai bahan perbandingan ketiga metode Fuzzy logic dengan tujuan dapat memudahkan dalam menentukan keluarga miskin berdasarkan kriteria yang sudah ditentukan oleh pemerintah.

\section{Metode}

Pada penelitian ini, pada tahapan penerapan Logika fuzzy secara umum memiliki tahapan pengerjaan sebagai berikut:

1. Membentuk himpunan fuzzy.

2. Fuzzyfication.

3. Inference.

4. Defuzzyfication.

5. Output.

\subsection{Tahapan Fuzzy Tsukamoto}

Saat proses evaluasi aturan dalam mesin inferensi, metode fuzzy Tsukamoto menggunakan fungsi implikasi MIN untuk mendapatkan nilai $\alpha$ predikat tiap-tiap rule $(\alpha 1, \alpha 2, \alpha 3, \ldots . \alpha n)$. Masingmasing nilai $\alpha$-predikat digunakan untuk menghitung hasil inferensi secara tegas (crisp) masing-masing rule (z1, z2, z3,... zn).

Metode Tsukamoto menggunakan metode ratarata (Average) dengan persamaan (1):

$$
\mathrm{z}=\frac{\sum \alpha_{1} \mathrm{z}_{1}}{\sum \alpha_{1}}
$$

\subsection{Tahapan Fuzzy Sugeno}

Metode Sugeno mirip dengan metode Mamdani, hanya output (konsekuen) tidak berupa himpunan fuzzy, melainkan berupa konstanta atau persamaan linier. Ada dua model metode Sugeno yaitu model fuzzy Sugeno orde nol dan model fuzzy Sugeno orde satu. Bentuk umum model fuzzy Sugeno orde nol adalah :

$$
\begin{aligned}
& \mathrm{IF}(\mathrm{x} 1 \text { is } \mathrm{A} 1 \mathrm{i}) \text { o (x2 isA2i) o ... o (xNisANi) THENz } \\
& =\mathrm{k}
\end{aligned}
$$

Bentuk umum model fuzzy Sugeno orde satu adalah:

IF (x1is A1i) o (x2 isA2i) o ... o (XNisAN)THEN $\mathrm{z}=\mathrm{p} 1 * \mathrm{x} 1+\ldots+\mathrm{pN} * \mathrm{xN}+\mathrm{q}$ 
Metode Tsukamoto menggunakan metode ratarata (Average) dengan persamaan (2) berikut :

$$
z=\frac{\sum \alpha_{1} z_{1}}{\sum \alpha_{1}}
$$

\subsection{Tahapan Fuzzy Mamdani}

Saat melakukan evaluasi aturan dalam mesin inferensi, metode Mamdani menggunakan fungsi MIN dan komposisi antar rule menggunakan fungsi MAX untuk menghasilkan himpunan fuzzy baru. Metode Mamdani sering juga dikenal dengan nama metode Max-Min. Pada Metode Mamdani, fungsi implikasi yang digunakan adalah Min. Secara umum dapat dinyatakan sebagai:

$$
\mu_{A \cap B}=\min \left(\mu_{A}[x],\left(\mu_{B}[x],\right)\right)
$$

Proses defuzzyfikasi pada metode Mamdani menggunakan metode Centroid dengan rumus berikut:

$$
\mathrm{z}=\frac{\int \mu(\mathrm{z}) \cdot \mathrm{zdz}}{\int \mu(\mathrm{z}) d z}
$$

\section{Hasil dan Pembahasan}

Pada penelitian ini dilakukan pengujian Fuzzy Logic metode Tsukamoto, Sugeno, dan Mamdani dalam menentukan keluarga miskin dengan maksud apakah metode Fuzzy Logic ini dapat menentukan keluarga miskin berdasarkan kriteria yang ditentukan oleh BPS (Badan Pusat Statistika) dan dari hasil pengujian ketiga metode Fuzzy Logic tersebut.

Dilihat dari prosedur yang berlaku dalam menentukan keluarga miskin dengan kriteria BPS (Badan Pusat Statistika) perlu adanya penghitungan dan menentukan sembilan variabel yang terpenuhi dari kriteria yang ditentukan oleh BPS (Badan Pusat Statistika) dilihat dari data rumah tangga yang disajikan sesuai dengan 14 kriteria tersebut.

Adapun indikator yang digunakan ada sebanyak 14 variabel, yaitu :

1. Luas lantai : $\{$ Kecil, Besar $\}$

2. Kualitas lantai : $\{$ Rendah, Tinggi $\}$

3. Kualitas dinding : $\{$ Rendah, Tinggi $\}$

4. Kualitas kamar mandi : \{Rendah, Tinggi $\}$

5. Kualitas penerangan : $\{$ Rendah, Tinggi $\}$

6. Kualitas air minum : $\{$ Rendah, Tinggi $\}$

7. Kualitas bahan bakar : \{Rendah, Tinggi $\}$

8. Frekuensi konsumsi daging : $\{$ Rendah, Tinggi $\}$

9. Frekuensi membeli pakaian : \{Rendah, Tinggi $\}$

10. Frekuensi makan : \{Rendah, Tinggi $\}$

11. Akses pengobatan : $\{$ Rendah, Tinggi $\}$

12. Penghasilan : $\{$ Sedikit, Banyak $\}$

13. Level pendidikan : $\{$ Rendah, Tinggi $\}$

14. Aset : \{Sedikit, Banyak $\}$

\subsection{Fuzzyfication}

'Fungsi derajat keanggotaan yang dapat dibentuk untuk setiap kriteria adalah sebagai berikut: 1) Luas Lantai : $\{$ Kecil, Besar $\}$

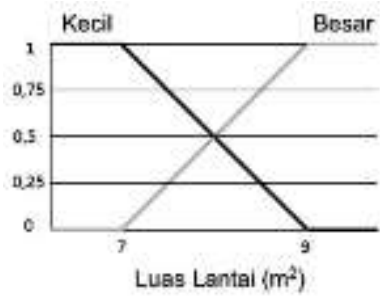

Gambar 1. Fungsi derajat keanggotaan variabel luas lantai

Definisi fungsi derajat keanggotaan pada Gambar 1 ditunjukkan pada Persamaan (5) dan Persamaan (6).

$\mu_{\text {Kecil }}(x)=\left\{\begin{array}{cc}0, & x \geq 9 \\ \frac{9-x}{9-7}, & 7<x<9 \\ 1, & x \leq 7\end{array}\right.$

$\mu_{\text {Besar }}(x)=\left\{\begin{array}{cc}0, & x \leq 7 \\ \frac{x-7}{9-7}, & 7<x<9 \\ 1, & x \geq 9\end{array}\right.$

2) Kualitas lantai : $\{$ Rendah, Tinggi $\}$

Nilai-nilai pada variabel kualitas lantai merupakan nilai kualitatif sehingga perlu diubah terlebih dahulu menjadi nilai skala seperti ditunjukkan pada Tabel 1

Tabel 1. Nilai skala variabel kualitas lantai

\begin{tabular}{|l|c|}
\hline \multicolumn{1}{|c|}{ Kualitas Lantai } & Nilai \\
\hline Tanah & 1 \\
\hline Bambu & 2 \\
\hline Kayu & 3 \\
\hline Semen & 4 \\
\hline Ubin & 5 \\
\hline Keramik & 6 \\
\hline
\end{tabular}

Fungsi derajat keanggotaan dari variabel kualitas lantai ditunjukkan pada Gambar 2.

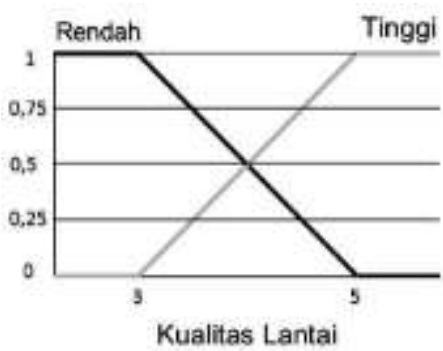

Gambar 2. Fungsi derajat keanggotaan variabel kualitas lantai 
Definisi fungsi derajat keanggotaan pada Gambar 2 ditunjukkan pada Persamaan (7) dan Persamaan (8).

$\mu_{\text {Rendah }}(x)=\left\{\begin{array}{cc}0, & x \geq 5 \\ \frac{5-x}{5-3}, & 3<x<5 \\ 1, & x \leq 3\end{array}\right.$

$\mu_{\text {Tinggi }}(x)=\left\{\begin{array}{cc}0, & x \leq 3 \\ \frac{x-3}{5-3}, & 3<x<5 \\ 1, & x \geq 5\end{array}\right.$

3) Kualitas dinding : \{Rendah, Tinggi $\}$

Nilai-nilai pada variabel kualitas dinding merupakan nilai kualitatif sehingga perlu diubah terlebih dahulu menjadi nilai skala seperti ditunjukkan pada Tabel 2.

Tabel 2. Nilai skala variabel kualitas dinding

\begin{tabular}{|l|c|}
\hline \multicolumn{1}{|c|}{ Kualitas Dinding } & Nilai \\
\hline Bambu & 1 \\
\hline Kayu & 2 \\
\hline Tembok & 3 \\
\hline
\end{tabular}

Fungsi derajat keanggotaan dari variabel kualitas dinding ditunjukkan pada Gambar 3.

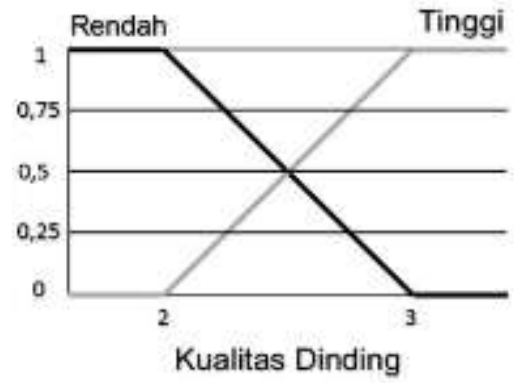

Gambar 3. Fungsi derajat keanggotaan variabel kualitas dinding

Definisi fungsi derajat keanggotaan pada Gambar 3 ditunjukkan pada Persamaan (9) dan Persamaan (10).

$\mu_{\text {Rendah }}(x)=\left\{\begin{array}{cc}0, & x \geq 3 \\ \frac{3-x}{3-2}, & 2<x<3 \\ 1, & x \leq 2\end{array}\right.$

$\mu_{\text {Tinggi }}(x)=\left\{\begin{array}{cc}0, & x \leq 2 \\ \frac{x-2}{3-2}, & 2<x<3 \\ 1, & x \geq 3\end{array}\right.$
4) Kualitas kamar mandi : \{Rendah, Tinggi $\}$

Nilai-nilai pada variabel kualitas kamar mandi merupakan nilai kualitatif sehingga perlu diubah terlebih dahulu menjadi nilai skala seperti ditunjukkan pada Tabel 3.

Tabel 3. Nilai skala variabel kualitas kamar mandi

\begin{tabular}{|l|c|}
\hline Kualitas Kamar Mandi & Nilai \\
\hline Tidak Ada & 1 \\
\hline Ada & 2 \\
\hline
\end{tabular}

Fungsi derajat keanggotaan dari variabel kualitas kamar mandi ditunjukkan pada Gambar 4

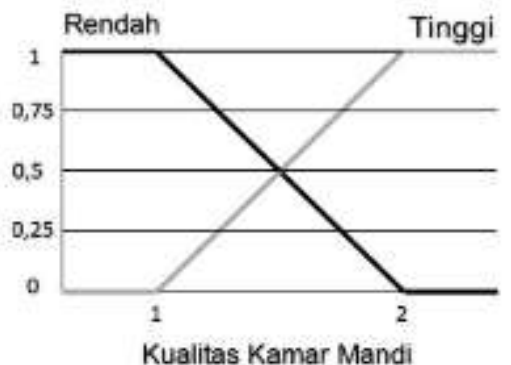

Gambar 4. Fungsi derajat keanggotaan variabel kualitas kamar mandi

Definisi fungsi derajat keanggotaan pada Gambar 4 ditunjukkan pada Persamaan (11) dan Persamaan (12).

$\mu_{\text {Rendah }}(x)=\left\{\begin{array}{cc}0, & x \geq 2 \\ \frac{2-x}{2-1}, & 1<x<2 \\ 1, & x \leq 1\end{array}\right.$
$\mu_{\text {Tinggi }}(x)=\left\{\begin{array}{cc}0, & x \leq 1 \\ \frac{x-1}{2-1}, & 1<x<2 \\ 1, & x \geq 2\end{array}\right.$

5) Kualitas penerangan : \{Rendah, Tinggi $\}$

Nilai-nilai pada variabel kualitas penerangan merupakan nilai kualitatif sehingga perlu diubah terlebih dahulu menjadi nilai skala seperti ditunjukkan pada Tabel 4.

Tabel 4. Nilai skala variabel kualitas penerangan

\begin{tabular}{|c|c|}
\hline Kualitas Penerangan & Nilai \\
\hline Bukan Listrik & 1 \\
\hline Listrik & 2 \\
\hline
\end{tabular}

Fungsi derajat keanggotaan dari variabel kualitas penerangan ditunjukkan pada Gambar 5 


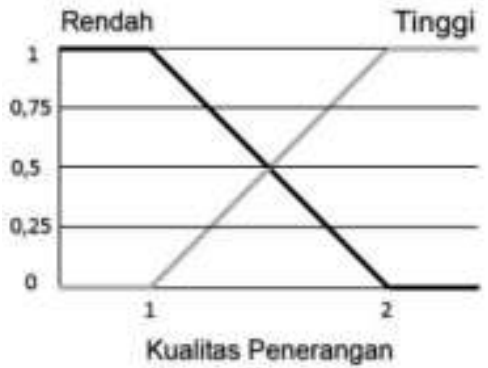

Gambar 5. Fungsi derajat keanggotaan variabel kualitas penerangan

Definisi fungsi derajat keanggotaan pada Gambar 5 ditunjukkan pada Persamaan (13) dan Persamaan (14).

$\mu_{\text {Rendah }}(x)=\left\{\begin{array}{cc}0, & x \geq 2 \\ \frac{2-x}{2-1}, & 1<x<2 \\ 1, & x \leq 1\end{array}\right.$

$\mu_{\text {Tinggi }}(x)=\left\{\begin{array}{cc}0, & x \leq 1 \\ \frac{x-1}{2-1}, & 1<x<2 \\ 1, & x \geq 2\end{array}\right.$

6) Kualitas air minum : \{Rendah, Tinggi $\}$

Nilai-nilai pada variabel kualitas air minum merupakan nilai kualitatif sehingga perlu diubah terlebih dahulu menjadi nilai skala seperti ditunjukkan pada Tabel 5.

Tabel 5. Nilai skala variabel kualitas air minum

\begin{tabular}{|c|c|}
\hline Kualitas Air Minum & Nilai \\
\hline Sungai & 1 \\
\hline Sumur & 2 \\
\hline PDAM & 3 \\
\hline Air Mineral & 4 \\
\hline
\end{tabular}

Fungsi derajat keanggotaan dari variabel kualitas air minum ditunjukkan pada Gambar 6.

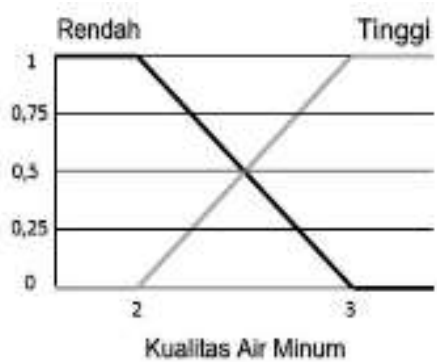

Gambar 6. Fungsi derajat keanggotaan variabel kualitas air minum

Definisi fungsi derajat keanggotaan pada Gambar 6 ditunjukkan pada Persamaan (15) dan Persamaan (16).

$\mu_{\text {Rendah }}(x)=\left\{\begin{array}{cc}0, & x \geq 3 \\ \frac{3-x}{3-2}, & 2<x<3 \\ 1, & x \leq 2\end{array}\right.$ $\mu_{\text {Tinggi }}(x)=\left\{\begin{array}{cc}0, & x \leq 2 \\ \frac{x-2}{3-2}, & 2<x<3 \\ 1, & x \geq 3\end{array}\right.$

7) Kualitas bahan bakar : \{Rendah, Tinggi $\}$

Nilai-nilai pada variabel kualitas bahan bakar merupakan nilai kualitatif sehingga perlu diubah terlebih dahulu menjadi nilai skala seperti ditunjukkan pada Tabel 6

Tabel 6. Nilai skala variabel kualitas bahan bakar

\begin{tabular}{|c|c|}
\hline Kualitas Bahan Bakar & Nilai \\
\hline Kayu Bakar & 1 \\
\hline Minyak Tanah & 2 \\
\hline LPG & 3 \\
\hline
\end{tabular}

Fungsi derajat keanggotaan dari variabel kualitas bahan bakar ditunjukkan pada Gambar 7

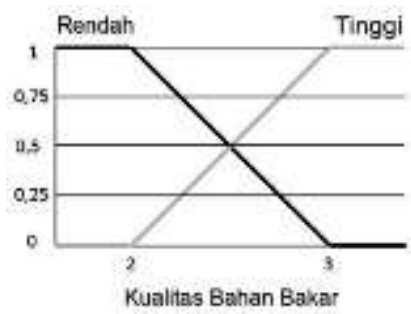

Gambar 7. Fungsi derajat keanggotaan variabel kualitas bahan bakar

Definisi fungsi derajat keanggotaan pada Gambar 7 ditunjukkan pada Persamaan (17) dan Persamaan (18).

$\mu_{\text {Rendah }}(x)=\left\{\begin{array}{cc}0, & x \geq 3 \\ \frac{3-x}{3-2}, & 2<x<3 \\ 1, & x \leq 2\end{array}\right.$

$\mu_{\text {Tinggi }}(x)=\left\{\begin{array}{cc}0, & x \leq 2 \\ \frac{x-2}{3-2}, & 2<x<3 \\ 1, & x \geq 3\end{array}\right.$

8) Frekuensi konsumsi daging : \{Rendah, Tinggi $\}$

Fungsi derajat keanggotaan dari variabel frekuensi konsumsi daging ditunjukkan pada Gambar 8

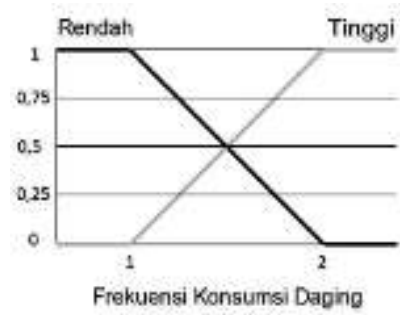

Gambar 8. Fungsi derajat keanggotaan variabel frekuensi konsumsi daging 
Definisi fungsi derajat keanggotaan pada Gambar 8 ditunjukkan pada Persamaan (19) dan Persamaan (20).

$\mu_{\text {Rendah }}(x)=\left\{\begin{array}{cc}0, & x \geq 2 \\ \frac{2-x}{2-1}, & 1<x<2 \\ 1, & x \leq 1\end{array}\right.$

$\mu_{\text {Tinggi }}(x)=\left\{\begin{array}{cc}0, & x \leq 1 \\ \frac{x-1}{2-1}, & 1<x<2 \\ 1, & x \geq 2\end{array}\right.$

9) Frekuensi membeli pakaian : \{Rendah, Tinggi $\}$

Fungsi derajat keanggotaan dari variabel frekuensi membeli pakaian ditunjukkan pada Gambar 9

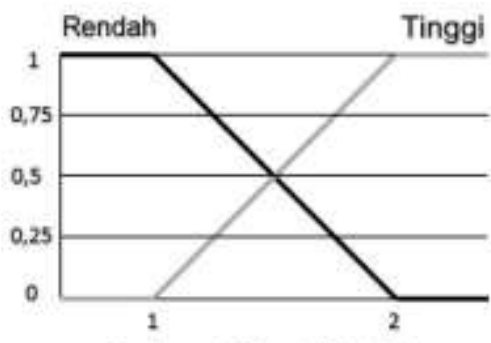

Frekuensi Membeli Pakaian

Gambar 9. Fungsi derajat keanggotaan variabel frekuensi membeli pakaian

Definisi fungsi derajat keanggotaan pada Gambar 9 ditunjukkan pada Persamaan (21) dan Persamaan (22).

$\mu_{\text {Rendah }}(x)=\left\{\begin{array}{cc}0, & x \geq 2 \\ \frac{2-x}{2-1}, & 1<x<2 \\ 1, & x \leq 1\end{array}\right.$

$\mu_{\text {Tinggi }}(x)=\left\{\begin{array}{cc}0, & x \leq 1 \\ \frac{x-1}{2-1}, & 1<x<2 \\ 1, & x \geq 2\end{array}\right.$

10)Frekuensi makan : \{Rendah, Tinggi $\}$

Fungsi derajat keanggotaan dari variabel frekuensi makan ditunjukkan pada Gambar 10

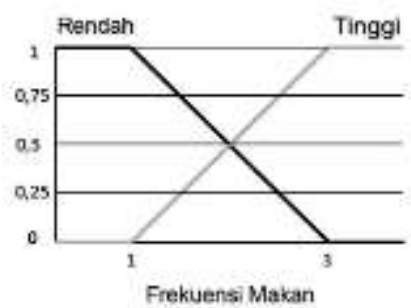

Gambar 10. Fungsi derajat keanggotaan variabel frekuensi makan
Definisi fungsi derajat keanggotaan pada Gambar 10 ditunjukkan pada Persamaan (23) dan Persamaan (24).

$\mu_{\text {Rendah }}(x)=\left\{\begin{array}{cc}0, & x \geq 3 \\ \frac{3-x}{3-1}, & 1<x<3 \\ 1, & x \leq 1\end{array}\right.$

$\mu_{\text {Tinggi }}(x)=\left\{\begin{array}{cc}0, & x \leq 1 \\ \frac{x-1}{3-1}, & 1<x<3 \\ 1, & x \geq 3\end{array}\right.$

11) Akses pengobatan : $\{$ Rendah, Tinggi $\}$

Nilai-nilai pada variabel akses pengobatan merupakan nilai kualitatif sehingga perlu diubah terlebih dahulu menjadi nilai skala seperti ditunjukkan pada Tabel 7

Tabel 7. Nilai skala variabel akses pengobatan

\begin{tabular}{|c|c|}
\hline Akses Pengobatan & Nilai \\
\hline Tidak Mampu & 1 \\
\hline Mampu & 2 \\
\hline
\end{tabular}

Fungsi derajat keanggotaan dari variabel akses pengobatan ditunjukkan pada Gambar 11

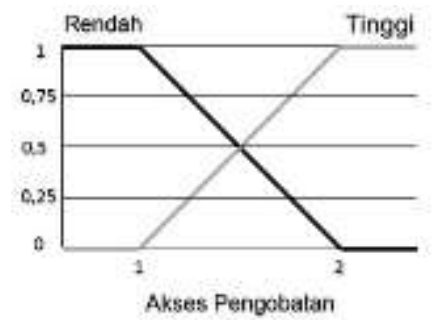

Gambar 11. Fungsi derajat keanggotaan variabel akses pengobatan

Definisi fungsi derajat keanggotaan pada Gambar 11 ditunjukkan pada Persamaan (25) dan Persamaan (26).

$\mu_{\text {Rendah }}(x)=\left\{\begin{array}{cc}0, & x \geq 2 \\ \frac{2-x}{2-1}, & 1<x<2 \\ 1, & x \leq 1\end{array}\right.$

$\mu_{\text {Tinggi }}(x)=\left\{\begin{array}{cc}0, & x \leq 1 \\ \frac{x-1}{2-1}, & 1<x<2 \\ 1, & x \geq 2\end{array}\right.$

12)Penghasilan : \{Sedikit, Banyak $\}$

Fungsi derajat keanggotaan dari variabel penghasilan ditunjukkan pada Gambar 12 


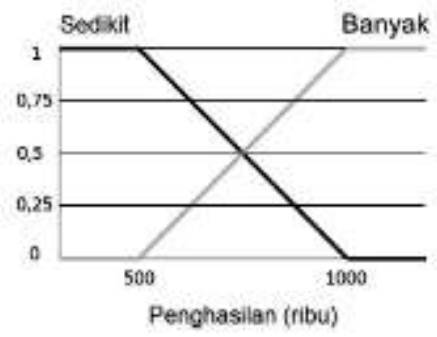

Gambar 12. Fungsi derajat keanggotaan variabel penghasilan

Definisi fungsi derajat keanggotaan pada Gambar 12 ditunjukkan pada Persamaan (27) dan Persamaan (28).

$\mu_{\text {Sedikit }}(x)=\left\{\begin{array}{cc}0, & x \geq 1000 \\ \frac{1000-x}{1000-500}, & 500<x<1000 \\ 1, & x \leq 500\end{array}\right.$

$\mu_{\text {Banyak }}(x)=\left\{\begin{array}{cc}0, & x \leq 500 \\ \frac{x-500}{1000-500}, & 500<x<1000 \\ 1, & x \geq 1000\end{array}\right.$

13) Level pendidikan : $\{$ Rendah, Tinggi $\}$

Nilai-nilai pada variabel level pendidikan merupakan nilai kualitatif sehingga perlu diubah terlebih dahulu menjadi nilai skala seperti ditunjukkan pada Tabel 8.

Tabel 8. Nilai skala variabel level pendidikan

\begin{tabular}{|c|c|}
\hline Level Pendidikan & Nilai \\
\hline Tidak Sekolah & 1 \\
\hline SD & 2 \\
\hline SMP & 3 \\
\hline SMA/SMK & 4 \\
\hline D3/S1/S2/S3 & 5 \\
\hline
\end{tabular}

Fungsi derajat keanggotaan dari variabel level pendidikan ditunjukkan pada Gambar 13

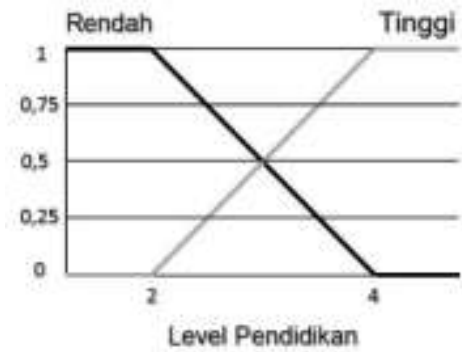

Gambar 13. Fungsi derajat keanggotaan variabel level pendidikan

Definisi fungsi derajat keanggotaan pada Gambar 13 ditunjukkan pada Persamaan (29) dan Persamaan (30).

$$
\begin{gathered}
\mu_{\text {Rendah }}(x)=\left\{\begin{array}{cc}
0, & x \geq 4 \\
\frac{4-x}{4-2}, & 2<x<4 \\
1, & x \leq 2
\end{array}\right. \\
\mu_{\text {Tinggi }}(x)=\left\{\begin{array}{cc}
0, & x \leq 2 \\
\frac{x-2}{4-2}, & 2<x<4 \\
1, & x \geq 4
\end{array}\right.
\end{gathered}
$$

14) Aset : $\{$ Sedikit, Banyak $\}$

Fungsi derajat keanggotaan dari variabel aset ditunjukkan pada Gambar 14.

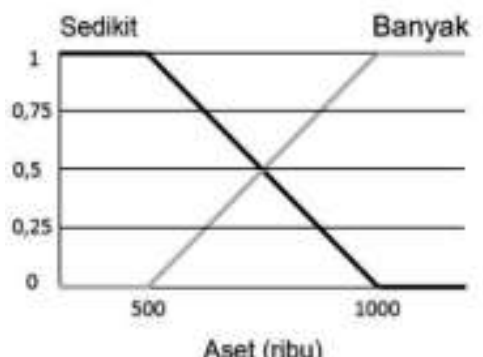

Gambar 14. Fungsi derajat keanggotaan variabel aset

Definisi fungsi derajat keanggotaan pada Gambar 14 ditunjukkan pada Persamaan (31) dan Persamaan (32).

$\mu_{\text {Sedikit }}(x)=\left\{\begin{array}{cc}0, & x \geq 1000 \\ \frac{1000-x}{1000-500}, & 500<x<1000 \\ 1, & x \leq 500\end{array}\right.$

$\mu_{\text {Banyak }}(x)=\left\{\begin{array}{cc}0, & x \leq 500 \\ \frac{x-500}{1000-500}, & 500<x<1000 \\ 1, & x \geq 1000\end{array}\right.$

15)Kategori Kemiskinan

Fungsi derajat keanggotaan dari variabel kategori kemiskinan ditunjukkan pada Gambar 15 .

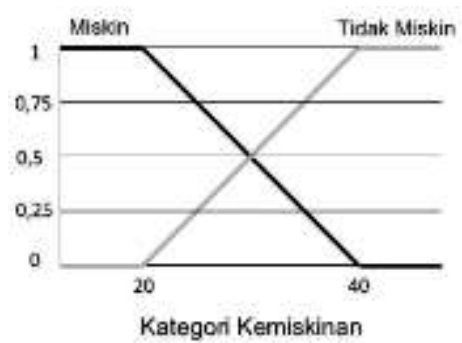

Gambar 4. Fungsi derajat keanggotaan kategori kemiskinan

Definisi fungsi derajat keanggotaan pada Gambar 15 ditunjukkan pada Persamaan (33) dan Persamaan (34). 
$\mu_{\text {Sedikit }}(x)=\left\{\begin{array}{cc}0, & x \geq 40 \\ \frac{40-x}{40-20}, & 20<x<40 \\ 1, & x \leq 20\end{array}\right.$

$\mu_{\text {Banyak }}(x)=\left\{\begin{array}{cc}0, & x \leq 20 \\ \frac{x-20}{40-20}, & 20<x<40 \\ 1, & x \geq 40\end{array}\right.$

\subsection{Mesin Inference}

Pada mesin inferensi dalam penentuan keluarga miskin, dilakukan dengan menggunakan tiga metode. Misalkan terdapat sebuah keluarga miskin yang memiliki nilai-nilai setiap kriteria sebagai berikut :

- Luas lantai

$: 7 \mathrm{~m}^{2}$

- Kualitas lantai

: Bambu

- Kualitas dinding

: Kayu

- Kualitas kamar mandi

: Ada

- Kualitas penerangan

: Bukan listrik

- Kualitas air minum

: Sungai

- Kualitas bahan bakar

: Kayu bakar

- Frekuensi konsumsi daging

: 0 x seminggu

- Frekuensi membeli pakaian

: 1 kali setahun

- Frekuensi makan

: 3 kali sehari

- Akses pengobatan

: Tidak mampu

- Penghasilan

- Level pendidikan

: Rp. 450.000

: SMP

- Aset

:Rp. 400.000

Himpunan bahasa yang dapat dibentuk berdasarkan nilai-nilai tersebut adalah sebagai barikut :

- Luas lantai

: $\{$ Kecil $\}$

- Kualitas lantai

: $\{$ Rendah $\}$

- Kualitas dinding

: $\{$ Rendah $\}$

- Kualitas kamar mandi : \{Tinggi $\}$

- Kualitas penerangan : $\{$ Rendah $\}$

- Kualitas air minum $\quad:\{$ Rendah $\}$

- Kualitas bahan bakar : \{Rendah $\}$

- Frekuensi konsumsi daging : \{Rendah $\}$

- Frekuensi membeli pakaian : $\{$ Rendah $\}$

- Frekuensi makan : $\{$ Tinggi $\}$

- Akses pengobatan $\quad:\{$ Rendah $\}$

- Penghasilan : $\{$ Sedikit $\}$

- Level pendidikan $\quad:\{$ Rendah, Tinggi $\}$

- Aset : $\{$ Sedikit $\}$

Nilai derajat keanggotaan setiap kriteria dihitung berdasarkan nilai-nilai input tersebut sehingga didapatkan hasil seperti ditunjukan pada Tabel 9.
Tabel 9. Nilai Himpunan

\begin{tabular}{|c|c|c|}
\hline No & Kriteria & Nilai Himpunan \\
\hline 1 & Luas lantai & $\begin{array}{l}\mu_{\text {Kecil }}(7)=1 \\
\mu_{\text {Besar }}(7)=0\end{array}$ \\
\hline 2 & Kualitas lantai & $\begin{array}{l}\mu_{\text {Rendah }}(2)=1 \\
\mu_{\text {Tinggi }}(2)=0\end{array}$ \\
\hline 3 & Kualitas dinding & $\begin{array}{l}\mu_{\text {Rendah }}(2)=1 \\
\mu_{\text {Tinggi }}(2)=0\end{array}$ \\
\hline 4 & $\begin{array}{l}\text { Kualitas kamar } \\
\text { mandi }\end{array}$ & $\begin{array}{l}\mu_{\text {Rendah }}(2)=0 \\
\mu_{\text {Tinggi }}(2)=1\end{array}$ \\
\hline 5 & Kualitas penerangan & $\begin{array}{l}\mu_{\text {Rendah }}(1)=1 \\
\mu_{\text {Tinggi }}(1)=0\end{array}$ \\
\hline 6 & Kualitas air minum & $\begin{array}{l}\mu_{\text {Rendah }}(1)=1 \\
\mu_{\text {Tinggi }}(1)=0\end{array}$ \\
\hline 7 & Kualitas bahan bakar & $\begin{array}{l}\mu_{\text {Rendah }}(1)=1 \\
\mu_{\text {Tinggi }}(1)=0\end{array}$ \\
\hline 8 & $\begin{array}{l}\text { Frekuensi konsumsi } \\
\text { daging }\end{array}$ & $\begin{array}{l}\mu_{\text {Rendah }}(0)=1 \\
\mu_{\text {Tinggi }}(0)=0\end{array}$ \\
\hline 9 & $\begin{array}{l}\text { Frekuensi membeli } \\
\text { pakaian }\end{array}$ & $\begin{array}{l}\mu_{\text {Rendah }}(1)=1 \\
\mu_{\text {Tinggi }}(1)=0\end{array}$ \\
\hline 10 & Frekuensi makan & $\begin{array}{l}\mu_{\text {Rendah }}(3)=0 \\
\mu_{\text {Tinggi }}(3)=1\end{array}$ \\
\hline 11 & Akses pengobatan & $\begin{array}{l}\mu_{\text {Rendah }}(1)=1 \\
\mu_{\text {Tinggi }}(1)=0\end{array}$ \\
\hline 12 & Penghasilan & $\begin{array}{l}\mu_{\text {Sedikit }}(450)=1 \\
\mu_{\text {Banyak }}(450) \\
=0\end{array}$ \\
\hline 13 & Level pendidikan & $\begin{array}{l}\mu_{\text {Rendah }}(3)=0,5 \\
\mu_{\text {Tinggi }}(3)=0,5\end{array}$ \\
\hline 14 & Aset & $\begin{array}{l}\mu_{\text {Sedikit }}(400)=1 \\
\mu_{\text {Banyak }}(400) \\
=0\end{array}$ \\
\hline
\end{tabular}

\subsubsection{Mesin Inference Tsukamoto}

Dalam mesin inferensi Fuzzy Tsukamoto menentukan rule yang sesuai dengan himpunan bahasa berdasarkan nilai derajat keanggotaan yang telah dihitung. Rule yang digunakan dalam contoh penghitungan :

a. R1 = Luas lantai KECIL, kualitas lantai RENDAH, kualitas dinding RENDAH, kualitas kamar mandi TINGGI, kualitas penerangan RENDAH, kualitas air minum RENDAH, kualitas bahan bakar RENDAH, frekuensi konsumsi daging RENDAH, frekuensi membeli pakaian RENDAH, frekuensi makan TINGGI, akses pengobatan RENDAH, penghasilan SEDIKIT, pendidikan TINGGI, dan aset SEDIKIT, maka rumah tangga tersebut termasuk MISKIN.

b. R2 = Luas lantai KECIL, kualitas lantai RENDAH, kualitas dinding RENDAH, kualitas kamar mandi TINGGI, kualitas penerangan RENDAH, kualitas air minum RENDAH, kualitas bahan bakar RENDAH, frekuensi konsumsi daging RENDAH, frekuensi membeli pakaian RENDAH, frekuensi makan TINGGI, 
akses pengobatan RENDAH, penghasilan SEDIKIT, pendidikan RENDAH, dan aset SEDIKIT, maka rumah tangga tersebut termasuk MISKIN.

Berdasarkan rule yang digunakan tersebut, nilai minimal derajat keanggotaan dari rule yang telah ditentukan dihitung sehingga didapatkan hasil seperti ditunjukkan pada Tabel 10.

Tabel 10. Nilai Minimal Derajat Keanggotaan

\begin{tabular}{|c|c|c|}
\hline Rule & Variabel & Nilai \\
\hline \multirow{15}{*}{1} & Luas lantai & 1 \\
\hline & Kualitas lantai & 1 \\
\hline & Kualitas dinding & 1 \\
\hline & Kualitas kamar mandi & 1 \\
\hline & Kualitas penerangan & 1 \\
\hline & Kualitas air minum & 1 \\
\hline & Kualitas bahan bakar & 1 \\
\hline & Frekuensi konsumsi daging & 1 \\
\hline & Frekuensi membeli pakaian & 1 \\
\hline & Frekuensi makan & 1 \\
\hline & Akses pengobatan & 1 \\
\hline & Penghasilan & 1 \\
\hline & Level pendidikan & 0,5 \\
\hline & Aset & 1 \\
\hline & $\mu_{1}$ & 0,5 \\
\hline \multirow{15}{*}{2} & Luas lantai & 1 \\
\hline & Kualitas lantai & 1 \\
\hline & Kualitas dinding & 1 \\
\hline & Kualitas kamar mandi & 1 \\
\hline & Kualitas penerangan & 1 \\
\hline & Kualitas air minum & 1 \\
\hline & Kualitas bahan bakar & 1 \\
\hline & Frekuensi konsumsi daging & 1 \\
\hline & Frekuensi membeli pakaian & 1 \\
\hline & Frekuensi makan & 1 \\
\hline & Akses pengobatan & 1 \\
\hline & Penghasilan & 1 \\
\hline & Level pendidikan & 0,5 \\
\hline & Aset & 1 \\
\hline & $\mu_{2}$ & 0,5 \\
\hline
\end{tabular}

\subsubsection{Mesin Inference Sugeno}

Dalam mesin inferensi Fuzzy Sugeno menentukan rule yang sesuai dengan himpunan bahasa berdasarkan nilai derajat keanggotaan yang telah dihitung. Rule yang digunakan dalam contoh penghitungan :

R1 = Luas lantai KECIL, kualitas lantai RENDAH, kualitas dinding RENDAH, kualitas kamar mandi TINGGI, kualitas penerangan RENDAH, kualitas air minum RENDAH, kualitas bahan bakar RENDAH, frekuensi konsumsi daging RENDAH, frekuensi membeli pakaian RENDAH, frekuensi makan TINGGI, akses pengobatan RENDAH, penghasilan SEDIKIT, pendidikan TINGGI, dan aset SEDIKIT THEN kategori miskin MISKIN(20).
Jika rule pada mesin inferensi Sugeno mendapatkan hasil MISKIN maka rule tersebut dipasangkan dengan nilai 20 sebagai nilai $\mathrm{z}$, apabila rule hasil TIDAK MISKIN maka rule tersebut dipasangkan dengan nilai 40 sebagai nilai z.

Berdasarkan rule yang digunakan tersebut, nilai minimal derajat keanggotaan dari rule yang telah ditentukan dihitung sehingga didapatkan hasil seperti ditunjukkan pada Tabel 11.

Tabel 11. Nilai Minimal Derajat Keanggotaan

\begin{tabular}{|l|l|l|}
\hline Rule & Variabel & Nilai \\
\hline \multirow{4}{*}{} & Luas lantai & 1 \\
\cline { 2 - 3 } & Kualitas lantai & 1 \\
\cline { 2 - 3 } & Kualitas dinding & 1 \\
\cline { 2 - 3 } & Kualitas kamar mandi & 1 \\
\cline { 2 - 3 } & Kualitas penerangan & 1 \\
\cline { 2 - 3 } & Kualitas air minum & 1 \\
\cline { 2 - 3 } & Kualitas bahan bakar & 1 \\
\cline { 2 - 3 } & Frekuensi konsumsi daging & 1 \\
\cline { 2 - 3 } & Frekuensi membeli pakaian & 1 \\
\cline { 2 - 3 } & Frekuensi makan & 1 \\
\cline { 2 - 3 } & Akses pengobatan & 1 \\
\cline { 2 - 3 } & Penghasilan & 1 \\
\cline { 2 - 3 } & Level pendidikan & 0,5 \\
\cline { 2 - 3 } & Aset & 1 \\
\cline { 2 - 3 } & $\mu_{1}$ & $\mathbf{0 , 5}$ \\
\hline
\end{tabular}

\subsubsection{Mesin Inference Mamdani}

Dalam mesin inferensi Fuzzy Mamdani dalam menentukan fungsi implikasi sama seperti metode Tsukamoto dan Sugeno yaitu menggunakan MIN pada semua rule namun pada metode Mamdani harus membuat komposisi antar rule.

Untuk menentukan komposisi antar aturan menggunakan MAX dengan membuat kurva baru seperti gambar 16 .

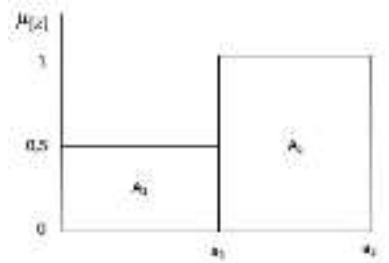

Gambar 5. Komposisi antar aturan

Kemudian, niali $\mathrm{a}_{1}$ dan $\mathrm{a}_{2}$ didapat :

$\frac{a_{1}-20}{40-20}=0,5--->\mathrm{a}_{1}=30$
$\frac{a_{2}-20}{40-20}=1 \quad--->>\mathrm{a}_{2}=40$

Dengan demikian, fungsi keanggotaan untuk himpunan fuzzy baru adalah: 
$\mu_{[z]}=\left\{\begin{array}{c}0,5, \quad z \leq 30 \\ 1, \quad z \geq 40\end{array}\right.$

\subsection{Defuzzyfication}

\subsubsection{Defuzzyfication Tsukamoto}

Pada proses defuzzyfication ini, dilakukan perhitungan nilai $\mathrm{z}$ untuk rule yang digunakan. Perhitungan nilai $\mathrm{z}$ untuk rule yang digunakan sebagai berikut :

a. Rule 1 menyatakan keluarga tersebut tergolong kedalam kategori rumah tangga miskin, sehingga perhitungan nilai $\mathrm{z}$ dapat dihitung sebagai berikut :

$$
\begin{gathered}
Z_{1}=20+\mu_{1}(40-20)=20+0,5(20) \\
=30
\end{gathered}
$$

b. Rule 2 menyatakan keluarga tersebut tergolong kedalam kategori rumah tangga miskin, sehingga perhitungan nilai $\mathrm{z}$ dapat dihitung sebagai berikut :

$$
\begin{gathered}
Z_{2}=20+\mu_{1}(40-20)=20+0,5(20) \\
=30
\end{gathered}
$$

Langkah selanjutnya adalah melakukan perkalian antara nilai $\mu$ dan $\mathrm{z}$ untuk setiap rule sehingga didapatkan hasil seperti tabel 12 .

Tabel 12 Hasil perhitungan $\boldsymbol{\mu}$ dan z

\begin{tabular}{|l|l|l|l|}
\hline Rule & Nilai $\boldsymbol{\mu}$ & Nilai $\mathbf{Z}$ & Nilai $\boldsymbol{\mu} * \mathbf{z}$ \\
\hline 1 & 0,5 & 30 & 15 \\
\hline 2 & 0,5 & 30 & 15 \\
\hline Total & 1 & 60 & 30 \\
\hline
\end{tabular}

Untuk mendapatkan perkiraan kategori kemiskinan, langkah selanjutnya adalah membagi nilai total $\mu * \mathrm{Z}$ dengan nilai total $\mu$, sehingga didapatkan hasil sebagai berikut :

$$
\text { Perkiraan }=\frac{\sum \mu * \mathrm{z}}{\sum \mu}=\frac{30}{1}=30
$$

Berdasarkan hasil perhitungan tersebut, nilai perkiraan yang diperoleh adalah 30 . Nilai inilah yang akan digunakan untuk menentukan prioritas rumah tangga miskin dengan cara membandingkan nilai hasil perhitungan antar rumah tangga.

\subsubsection{Defuzzyfication Sugeno}

Pada proses defuzzyfication ini, dilakukan perhitungan nilai $\mathrm{Z}$ untuk rule yang digunakan. Perhitungan nilai $\mathrm{Z}$ untuk mendapatkan perkiraan kategori kemiskinan sehingga didapatkan hasil sebagai berikut :

$$
Z=\frac{\sum \mu * \mathrm{Z}}{\sum \mu}=\frac{0,5 * 20}{0,5}=\frac{10}{0,5}=20
$$

Berdasarkan hasil perhitungan tersebut, nilai perkiraan yang diperoleh adalah 20. Nilai inilah yang akan digunakan untuk menentukan prioritas rumah tangga miskin dengan cara membandingkan nilai hasil perhitungan antar rumah tangga.

\subsubsection{Defuzzyfication Mamdani}

Pada proses defuzzyfication ini, dilakukan perhitungan nilai $\mathrm{Z}$ untuk rule yang digunakan. Perhitungan nilai $\mathrm{Z}$ untuk mendapatkan perkiraan kategori kemiskinan sehingga didapatkan hasil sebagi berikut:

$z^{*}=\frac{\int \mu(z) z d z}{\int \mu(z) d z}$

Menghitung Momen :

$M 1=\int_{0}^{30}(0,5) z d z=0,25 z^{2} \int_{0}^{30}=225$

$M 2=\int_{30}^{40}(1) z d z=0,5 z^{2} \int_{30}^{40}=350$

Menghitung Luas :

$A 1=30 \times 0,5=15$

$A 2=40 \times 1=40$

Menghitung titik pusat (terhadap z) :

$z^{*}=\frac{(225+350)}{(15+40)}=\frac{575}{55}=10,45$

Berdasarkan hasil perhitungan tersebut, nilai perkiraan yang diperoleh adalah 10,45 . Nilai inilah yang akan digunakan untuk menentukan prioritas rumah tangga miskin dengan cara membandingkan nilai hasil perhitungan antar rumah tangga

\subsection{Output}

Hasil perhitungan dari satu contoh data yang disajikan menggunakan fuzzy logic metode Tsukamoto, Sugeno, dan Mamdani didapat hasil metode Tsukamoto adalah 30, metode Sugeno adalah 20, dan metode Mamdani adalah 10,45. Nilai dari setiap metode akan dimasukan kedalam range nilai atau dapat dimasukan kedalam derajat keanggotaan kategori miskin untuk melihat apakah hasil dari perhitungan setiap data itu termasuk kedalam kategori miskin atau tidak dengan range nilai sebagai berikut:

Miskin $: x \leq 30$

Tidak Miskin : $30<x \leq 60$ 
Tabel 13. Hasil Perbandingan

\begin{tabular}{|l|c|c|c|}
\hline \multicolumn{1}{|c|}{ Rule } & Tsukamoto & Sugeno & Mamdani \\
\hline R10 & Tidak Miskin & Tidak Miskin & Tidak Miskin \\
\hline R13 & Tidak Miskin & Tidak Miskin & Tidak Miskin \\
\hline R3 & Tidak Miskin & Miskin & Miskin \\
\hline R10 & Tidak Miskin & Tidak Miskin & Tidak Miskin \\
\hline R9 & Tidak Miskin & Tidak Miskin & Tidak Miskin \\
\hline R14 & Tidak Miskin & Tidak Miskin & Miskin \\
\hline R10 & Tidak Miskin & Tidak Miskin & Tidak Miskin \\
\hline R4 & Tidak Miskin & Miskin & Miskin \\
\hline R15 & Miskin & Miskin & Miskin \\
\hline R2 & Miskin & Miskin & Miskin \\
\hline R10 & Tidak Miskin & Tidak Miskin & Tidak Miskin \\
\hline R11 & Tidak Miskin & Tidak Miskin & Tidak Miskin \\
\hline R7 & Miskin & Miskin & Miskin \\
\hline R8 & Tidak Miskin & Tidak Miskin & Tidak Miskin \\
\hline R12 & Tidak Miskin & Tidak Miskin & Tidak Miskin \\
\hline R5 & Tidak Miskin & Miskin & Miskin \\
\hline R14 & Tidak Miskin & Tidak Miskin & Miskin \\
\hline R10 & Tidak Miskin & Tidak Miskin & Tidak Miskin \\
\hline R6 & Tidak Miskin & Miskin & Miskin \\
\hline
\end{tabular}

Dengan memasukan hasil perhitungan ketiga metode kedalam persamaan didapat untuk metode Tsukamoto pada contoh data yang dihitung termasuk dalam kategori miskin dengan nilai 30 , hasil perhitungan metode Sugeno termasuk kedalam kategori miskin dengan nilai 20, dan hasil perhitungan pada metode Mamdani pada data yang menjadi contoh perhitungan termasuk kedalam kategori miskin dengan nilai 10,45.

\subsection{Evaluasi}

Berdasarkan hasil analysis, hasil yang didapatkan ditunjukan pada Tabel 13. Dari semua data yang dihitung menggunakan metode fuzzy logic metode Tsukamoto, Sugeno, dan Mamdani di tampilkan pada tabel diatas dapat disimpulkan bahwa pada metode Tsukamoto terdapat 4 data yang tergolong miskin dan 16 data yang tergolong tidak miskin, pada metode Sugeno terdapat 8 data yang tergolong miskin dan 12 data yang tergolong tidak miskin, dan pada metode Mamdani terdapat 10 data yang tergolong miskin dan 10 yang tergolong tidak miskin. Hasil tersebut menunjukan bahwa setiap metode memiliki hasil yang berbeda-beda walaupun input yang digunakan sama.

\section{Kesimpulan}

Dari uraian hasil penelitian yang dilakukan melalui dapat disimpulkan bahwa dari semua data yang dihitung menggunakan metode fuzzy logic metode Tsukamoto, Sugeno, dan Mamdani dapat disimpulkan bahwa pada metode Tsukamoto terdapat 4 data yang tergolong miskin dan 16 data yang tergolong tidak miskin, pada metode Sugeno terdapat 8 data yang tergolong miskin dan 12 data yang tergolong tidak miskin, dan pada metode
Mamdani terdapat 10 data yang tergolong miskin dan 10 yang tergolong tidak miskin. Hasil tersebut menunjukan bahwa setiap metode memiliki hasil yang berbeda-beda walaupun input yang digunakan sama. Dari hasil penerapan metode fuzzy metode Tsukamoto, Sugeno, dan Mamdani memiliki perbedaan dalam pengerjaan pada tahapan inferensi dan defuzzyficationnya.

\section{Daftar Pustaka}

[1] N. S. Wibowo, D. P. S. Setyohadi, and H. Rakhmad, "Penggunaan Metode Fuzzy Dalam Sistem Informasi Geografis Untuk Pemetaan Daerah Rawan Banjir Di Kabupaten Jember," Prosiding, vol. 0, no. 0, Dec. 2016.

[2] E. H. Jacobus, P. . Kindangen, and E. N. Walewangko, "Analisis Faktor-Faktor Yang Mempengaruhi Kemiskinan Rumah Tangga Di Sulawesi Utara," J. Pembang. Ekon. DAN Keuang. Drh., vol. 19, no. 7, Jul. 2019.

[3] P. D. Sugiyono, Metode penelitian kombinasi (mixed methods). Bandung: Alfabeta, 2015.

[4] L. P. Ayuningtias, M. irfan, and J. Jumadi, "Analisa Perbandingan Logic Fuzzy Metode Tsukamoto, Sugeno, Dan Mamdani (Studi Kasus : Prediksi Jumlah Pendaftar Mahasiswa Baru Fakultas Sains Dan Teknologi Universitas Islam Negeri Sunan Gunung Djati Bandung)," J. Tek. Inform. , vol. 10, no. 1, 2017.

[5] Y. Rohani, "Menentukan Tingkat Kemiskinan Menggunakan Fuzzy Logic," J. Khatulistiwa Inform., vol. 2, no. 1, Jun. 2014.

[6] W. F. Wijayaningrum, Vivi Nur Mahmudy, "Penentuan Prioritas Rumah Tangga Miskin Menggunakan Fuzzy Tsukamoto," in Seminar Nasional Teknologi Informasi dan 
Komunikasi2016 (SENTIKA 2016), 2016.

[7] A. N. Fauzan and P. D. B. M. M. K. -, "Sistem Pendukung Keputusan Penentuan Keluarga Miskin Di Kelurahan Pilangsari Kecamatan Gesi Dengan Menggunakan Metode Technique
For Order Performance By Similarity To Ideal Solution (Topsis)," Feb. 2017.

[8] A. Suharsimi, Prosedur penelitian suatu pendekatan praktik. Jakarta: Rineka Cipta, 2006. 